\title{
The Field of Logistics Warehouse Layout Analysis and Research
}

\author{
Wei Wang \\ Beijing Wuzi University, Beijing, China \\ Email: Wangwei199304@126.com
}

Received 25 May 2016; accepted 24 June 2016; published 27 June 2016

Copyright (C) 2016 by author and Scientific Research Publishing Inc.

This work is licensed under the Creative Commons Attribution International License (CC BY).

http://creativecommons.org/licenses/by/4.0/

(c) (i)

\section{Abstract}

Logistics warehouse layout problem in circulation is one of the issues the enterprise concerned; storage as a logistics hub for transport links plays a role in the protection of stored products. During storage planning, in order to design a reasonable layout of warehouses, companies must consider seasonal product, quantity demand characteristics and the treasury itself highly characteristic and so on. Handling the number of products and their performance, will certainly affect the design of the warehouse place; at the same time, with seasonal variations, warehouse receipt must not only be able to accommodate the capacity of the warehouse area and height for design, but also consider that forklift and artificial operation need some work area, and it cannot affect normal operation of the product by placeholder area.

\section{Keywords}

\section{Warehouse Layout, Storage Area, Work Functioning}

\section{Introduction}

In the field of logistics, the vendors need to provide goods; manufacturers and processors need to process products and distribution centers are for goods distribution. Goods will reach the final retail shops or consumers. This process is called logistics. In the range of logistics, there must be a cycling of goods in the circulation process. It is often that goods are not directly to reach the hands of consumers, or it is impossible in the process of transportation without interruption all the time, which is bound to have built warehouses for storage. The spatial layout's design is very important and which parts it can put goods will directly or indirectly affect the efficiency of commodity circulation stream, or affect the receipt time of goods, and even influence the service level of enterprise. Thus, it will affect the volatility of customer satisfaction. Therefore, it is very important to design warehousing and distribution; warehousing and internal displaying should be strictly carried out according to 
certain rules. It means that which goods need to be placed near the receiving area, which goods require stacking merchandise, companies should consider these issues as important factors. The field of logistics warehousing is a transport hub of logistics; if the storage space cannot be planned well, it would certainly have trouble in receiving and shipping. Thus it must affect the efficiency of logistics and transport or increase logistics costs. Finally, it will result in a downturn of the economy. Therefore, studying of the storage warehouse layout is very important in the field of logistics, such as the classification of warehousing, and the designing of goods.

\section{Current Situation}

Nowadays there are many scholars in the field of logistics warehouse layout in-depth study. Jiang and Feng Dingzhong cents (2013) two scholars from a wide range of point of view, the use of Matlab mathematical program run, calculate the warehouse layout most suitable angle for picking system to shorten the distance and time issues to provide a reliable theoretical proof [1]. Zhu Jianghong (2011) scholar for warehouse layout problems, from real-life examples of logistics park view, were the establishment of the index system, and ultimately the use of fuzzy mathematical evaluation proved the feasibility of the program [2]. Yang Xuechun and Mao Xiaofang two scholars (2014) for the storage of the problems, from the layout, process design, placement of goods warehouse in-depth study [3]. Xuan Ying and Chen (2013) for the Reserve for military supplies, the use of mathematical models of genetic algorithms, reasonable conclusions [4]. Li Yumin and Zhang Li (2012) for the rational distribution of pharmaceutical warehouse, logistics analysis using SLP, obtained important design warehouse layout [5]. Jiang Hua and Yang Maosheng (2008) for the external and internal environment of the warehouse, a comprehensive factor analysis, the rational distribution warehouse design [6]. According to many scholars research, we can know that is the importance of warehouse people can not be ignored. Warehousing logistics of agricultural products, aquatic products and other material storage and transportation, if can't good design, will bring items lost in the process of storage and transportation quality to drop, employees in the warehouse work efficiency could be greatly reduced. The purpose of this article and the above the breakthrough point is different, in this paper, the main innovation point is based on the size of the storage area, storage area computation formula, on the basis of the original study, joined the turnover of goods and factor analysis, make the calculation formula of storage area is more appropriate, and scholars differ from the point of view of the types of goods.

\section{Warehouse Layout Considerations Analysis}

Traditional companies often choose the storage layout PQRST layout analysis and research methods, PQRST method is the enterprise often select method, the method for design warehouse space, is in the enterprise, on the basis of the original data after large amounts of data statistics, a detailed classification and combination, for example, the demand for goods and goods handling times are combined to illustrate the location of the goods, etc., the factors considered in this method is not very comprehensive, PQRST method of storage of goods only from itself, just consider the number of moving goods demand, goods, the flow of goods, etc., this approach ignores the effective use of storage area of the warehouse, without the storage height and other factors into account and other channels, often for minor changes to the role of the warehouse. Therefore, this article from the storage area of this factor of view, the cargo area to classify optimization, taking into account the effective height of the Treasury, the effective channel, tray and shelf usage, etc., factors to consider more comprehensive, so that the internal layout of the warehouse more reasonable.

\subsection{Auxiliary Facilities Planning Area}

Storage area generally can be divided into two parts, one is the cargo storage area, area of this part is to meet footprint of goods, while the other part is that every business needs some fixing placeholder, for example: receiving areas for where to take delivery, delivery area, the place used to send goods, scan area, companies in order to record incoming and outgoing goods timely information system to facilitate the subsequent search, the scan area will be set up to facilitate the company's management. Set placeholder cargo area is also essential, because shipping and receiving, the company's personnel can not be placed directly on a shelf or storage location to the goods, because a large amount of goods, only the first set of goods stored in the zone, and then another part of the staff to go sorting goods. Work area where employees are managers doing things, often can 
not be ignored placeholder, such as supervision and management system, must have a fixed office space. Mentioned above it is essential for enterprise storage in the auxiliary facilities.

For auxiliary facilities in warehousing arrangement, under normal circumstances, we follow the process from starting, such as a business process after the storage of goods to be timely scan goods scanned are placed into the storage area for storage, storage after the classification of goods to be placed into their respective positions, waiting for demand comes after the timely collection of goods ready to ship cargo scanning. Under this process, the area of design aids in the process tend to be close to the department or footprint together to facilitate the management and shipping and receiving. For these regions, companies must be in the process of designing the warehouse, the shipping and receiving area, storage area, working out of such advance planning, so there is a macro to control, according to pre-planned area, the transceiver cargo area reasonable set according to the shape of warehousing. After the whole enterprise should be classified storage area, divided into equal units of the cell, and the cell area is clear how much, according to a work area required number of cells can be designed to meet their place.

\subsection{Storage Area of Planning}

In this paper, the above content is analyzed and summarized for auxiliary facilities in an area designed for the storage area of the goods, we often have to consider that the goods stacked way, because, if the goods are directly stacked on the spatial pattern of the Treasury, then enterprises only consider this product can be placed per unit area and commodity height and maximum load capacity of goods. If the goods pallet storage is required, then you need to consider how much a commodity tray to store a number of cargo storage tray can be factors in addition to the shelf area is to be considered. In addition, we have to consider whether you can put convergence between different goods, which requires an order of relevance systematic analysis, the correlation between the cargo and the cargo of a group of products is very high, you can consider whether put together, play a role in connecting and convenient shipping of goods.

For an area of storage, companies often have to calculate the storage area, for the same unit of the good, the size of the storage area and is often related to the annual purchase amount of goods, and is proportional to the relationship because of the size of the purchase amount determines the warehouse area size. In addition, the size and store the number of days the storage area of the product also has a relationship for a commodity, the logistics distribution process, if the number of days in a warehouse to store more, it will affect other goods into the warehouse storage area, turnover tends Days determine the degree of flexibility of the warehouse. At the same time, storage area and also the employees working hours usage per unit area and a storage area of the load-bearing capacity is related to and is inversely proportional relationship. After design and analysis, will be transformed storage area is calculated as follows:

$$
S=\frac{4 M * T}{T_{0} * q * W * P}
$$

Meaning the formula is as follows:

$S$ : Requirements of storage area was the area $\left(\mathrm{m}^{2}\right)$;

$M$ : Each quarter the amount of goods into the library $(\mathrm{t})$;

$T$ : The average number of days to store merchandise;

$q$ : Average effective carrying capacity storage area $\left(\mathrm{t} / \mathrm{m}^{2}\right)$;

$W$ : effective storage area utilization coefficient;

$T_{0}$ : Workers working days a year;

$P$ : the average annual turnover of goods.

We can analyze the results that the number of goods are into the library stored in the warehouse a few days of each quarter, and are proportional to the storage area of the inevitable relationship between the goods placed in the warehouse longer, it will inevitably take a lot of cargo storage area the same each quarter for the same commodities greater the amount of the purchase, will inevitably increase the storage area. In addition, for the carrying capacity of the warehouse unit, if the unit area can withstand the weight of large quantities of goods, you can put more goods cargo at the same height, so that the storage area occupied by smaller. Employee time also affects the enterprise storage area, employee long time, high efficiency and speed will make shipping and receiving goods faster, can largely meet the business running time and customer satisfaction services. The average 
turnover rate of goods determines the goods in cargo on time spent, the higher the turnover rate, the faster turnover of goods in the cargo space on the residence time is shortened, it will stay out of storage to another product area.

\subsection{Treasury Planning Height}

In theory, the height of the Treasury is the higher the better, however, since the load carrying capacity per unit area, often can not be unlimited increase also have to consider the optimal distance shelf height, the height of the Treasury issues. In general, the height of the Treasury to be designed in two ways. The first is the optimum height of the cargo, that is, without considering the height of the warehouse, the goods can be placed at the highest level and maximum distance, in addition, is the maximum distance from the Treasury, to set aside part of the distance to the Treasury Internal space staff check, sometimes in order to protect the product quality problems, but also to the warehouse environment supervision and commissioning, it is bound to installation of air conditioning appliances category, so the Treasury is bound to consider the height of the presence and influence of these factors.

But in real life, we inevitably have to consider the reservation forklift operation or manual operation. If the business is a way to take manual jobs in the design process, we must consider the workers put goods or pickup time whether there is sufficient channel area can be placed ladders and other tools, if the area is very small, high enough, it can not be easily taken out goods, affecting the quality of work of employees. If the business takes the job way forklift truck must be to allow sufficient space and access to meet the normal operation efficiency of the truck, we must also consider the effective height and the height of the truck can not conflict with the goods, must design Treasury reasonable height for easy handling and delivery of goods pickup truck.

\section{Summary}

The good or fall of logistics in the field of warehouse planning and inventory analysis will inevitably affect the enterprise operation efficiency and quality in the process of the flow of goods in the logistics. Enterprises also start from accepting the goods orders with PQRST method in the layout of the warehouse. They are able to predict the future demand according to the original data and design the suitable warehouse. There will be a big risk and an uncertain result of this method, because sometimes there are many seasonal goods and it will exist some random effects. So according to this method, to design the warehouse layout is not reasonable. According to the effective areas of warehouse and classification of the area for standardization, enterprises accept the goods orders and need to calculate the goods per unit area. Enterprises should choose the display shelves, forklift truck or other tools instead of artificial operation to reduce the working intensity and improve work efficiency.

\section{References}

[1] Jiang, C., Zhong, P.D., Zhao, Y.L. and Feng, Y.M. (2013) Fishbone Based on Improved Logistics Warehouse Layout. Systems Engineering Theory \& Practice, 11, 2920-2929.

[2] Zhu, J.H. (2011) Logistics Park Warehouse Layout to Improve the Design. Logistics Technology, 9, 131-134.

[3] Yang, X.C. and Mao, X.F. (2014) A Zang Chang Logistics Company Warehouse Layout and Workflow Analysis and Improvement. Hefei University (Natural Science), 4, 86-91.

[4] Xuan, Y., Chen, W., Zhu, O. and Qiu, F. (2013) Based on Immune Optimization Algorithm Military Supplies Warehouse Distribution Logistics Technology. Hefei University (Natural Science), 5, 471-473.

[5] Li, Y.M., Zhang, L. and Xiong, Y.W. (2012) Research SLP Intelligent Medicine Warehouse Layout Based Approach. Jiangsu Buyer Theory, 4, 31-33.

[6] Jiang, H. and Yang, M.S. (2008) Logistics Center Warehouse Layout Planning. New West (Second Half), 5, 34-35. 


\section{Submit or recommend next manuscript to SCIRP and we will provide best service for you:}

Accepting pre-submission inquiries through Email, Facebook, Linkedin, Twitter, etc A wide selection of journals (inclusive of 9 subjects, more than 200 journals)

Providing a 24-hour high-quality service

User-friendly online submission system

Fair and swift peer-review system

Efficient typesetting and proofreading procedure

Display of the result of downloads and visits, as well as the number of cited articles

Maximum dissemination of your research work

Submit your manuscript at: http://papersubmission.scirp.org/ 